\title{
Mast cell activation is characterized by upregulation of a functional anaphylatoxin $\mathbf{C 5 a}$ receptor Afsaneh Soruri, Jasmin Grigat, Ziba Kiafard and Jörg Zwirner*
}

\author{
Address: Department of Cellular and Molecular Immunology, Georg-August-University Göttingen, Humboldtallee 34, D-37073 Göttingen, \\ Germany \\ Email: Afsaneh Soruri - asoruri@gwdg.de; Jasmin Grigat - jasmin_grigat@web.de; Ziba Kiafard - zkiafard@web.de; \\ Jörg Zwirner* - jzwirne@gwdg.de \\ * Corresponding author
}

Published: 17 June 2008

BMC Immunology 2008, 9:29 doi:10.1 I86/147|-2172-9-29

This article is available from: http://www.biomedcentral.com/I47I-2I72/9/29

(C) 2008 Soruri et al; licensee BioMed Central Ltd.

This is an Open Access article distributed under the terms of the Creative Commons Attribution License (http://creativecommons.org/licenses/by/2.0), which permits unrestricted use, distribution, and reproduction in any medium, provided the original work is properly cited.
Received: 6 March 2008

Accepted: 17 June 2008

\begin{abstract}
Background: Mast cells (MC) are key effector cells of allergic diseases and resistance to helminthic parasites and induce or amplify diverse innate and adaptive immune responses. The signals controlling MC mobilization during inflammation are not fully understood.

Results: Since anaphylatoxins are attractive candidates as MC chemoattractants, we investigated expression and function of anaphylatoxin receptors in murine MC. Precursor cell-derived MC cultured with IL- 3 in the presence or absence of SCF did not express significant amounts of surface $\mathrm{C} 5 \mathrm{a}$ receptor $(\mathrm{C} 5 \mathrm{aR})$ or $\mathrm{C} 3 \mathrm{a}$ receptor $(\mathrm{C} 3 \mathrm{aR})$. MC required approximately $4 \mathrm{~h}$ of stimulation with $\mathrm{Ag}$ (DNP-albumin, following preincubation with $\mathrm{g} \mathrm{E}$ anti-DNP), ionomycin, or PMA to enable a strong chemotactic response towards $\mathrm{C} 5 \mathrm{a}$, paralleled by a distinct $\mathrm{C} 5 \mathrm{aR}$ upregulation. Likewise, $\mathrm{C} 5 \mathrm{a}$ induced intracellular calcium fluxes solely in activated MC. In contrast, C3a proved to be a weak MC chemotaxin and unable to increase intracellular calcium. Primary peritoneal MC did not express detectable amounts of anaphylatoxin receptors, however, similar to precursor cell-derived $M C$, stimulation with $\mathrm{Ag}$ or ionomycin for $4 \mathrm{~h}$ induced a prominent surface expression of $\mathrm{C} 5 \mathrm{aR}$ whereas $\mathrm{C} 3 \mathrm{aR}$ remained undetectable.
\end{abstract}

Conclusion: Collectively, our results suggest that Ag-dependent as well as -independent activation induces an inflammatory $M C$ phenotype which is distinguished by neoexpression of a functional $\mathrm{C} 5 \mathrm{aR}$ as a novel effector mechanism in MC-mediated pathogenesis.

\section{Background}

Many forms of infection or tissue injury lead to activation of the complement system resulting in the cleavage of complement components $\mathrm{C} 3$ and $\mathrm{C} 5$ and generation of the anaphylatoxins C3a and C5a [1]. Anaphylatoxins are responsible for recruiting and activating leukocytes, particularly phagocytic cells such as granulocytes and monocytes/macrophages and are involved in inflammatory, autoimmune and allergic diseases [2-4]. Anaphylatoxins perform their functions by engaging specific receptors which are closely related members of the rhodopsin family of seven transmembrane-spanning $G$ protein-linked receptors.

MC have long been described as effectors of IgE-dependent immuneresponses that mediate immediate hypersensitivity reactions associated with allergic phenomena and host resistance to helminthic parasites, and are now also 
implicated in different autoimmune and inflammatory disease models $[5,6]$.

The signals controlling MC recruitment and migration within tissues are poorly understood, but anaphylatoxins are particularly attractive candidates as MC chemoattractants during inflammation. In humans, for example, skinderived MC have been shown to be sensitive to C5a and C3a whereas MC from the lung were not [7-10]. Studies with the immature human mast cell line HMC-1 even suggested C3a to be one of the most effective mast cell chemoattractants $[11,12]$. Furthermore, anaphylatoxin receptor expression may depend on variations in the local microenvironment since synovial MC expressed C5aR exclusively in inflamed tissue of rheumatoid arthritis patients $[13,14]$.

The understanding of the pathophysiological and biochemical basis of the differential expression of anaphylatoxin receptors on MC subtypes is hampered by our scarce, sometimes controversial knowledge on the expression of anaphylatoxin receptors in rodent MC. Whereas $\mathrm{C} 5 \mathrm{a}$ was able to degranulate skin-derived murine $\mathrm{MC}$, peritoneal $\mathrm{MC}$ were found to be unresponsive [15]. On the other hand, C5aR on peritoneal MC was observed to be instrumental in a mouse model of zymosan-mediated peritonitis [16] whereas rat peritoneal MC degranulated in response to $\mathrm{C} 3 \mathrm{a}$ and $\mathrm{C} 3 \mathrm{a}(\mathrm{des} A r g)$ by a receptor-independent mechanism [17]. Clearly, studies of the interactions between $\mathrm{MC}$ and anaphylatoxins are still in their infancy despite their well-appreciated roles in allergy, infection and autoimmunity.

The purpose of the present study was (1) to investigate the impact of different modes of MC activation on the expression and function of anaphylatoxin receptors, (2) to compare precursor cell-derived $\mathrm{MC}$ generated in vitro with primary MC purified from the peritoneal cavity, and (3) to uncover differences in the expression profiles of $\mathrm{C} 5 \mathrm{aR}$ and C3aR.

\section{Results}

Anaphylatoxin receptors on in vitro generated $M C$

Murine precursor cell-derived MC cultured in the presence of IL-3 and SCF were investigated for anaphylatoxin receptor expression using specific $\mathrm{mAb}$ against $\mathrm{C} 5 \mathrm{aR}$ and $\mathrm{C} 3 \mathrm{aR}$, respectively. Anaphylatoxin receptor levels were found to be below the theshold of flow cytometric detection on resting MC. However, MC stimulation for $24 \mathrm{~h}$ with the calcium ionophore ionomycin, the protein kinase $\mathrm{C}$ activator PMA or Ag (DNP-albumin, following a $24 \mathrm{~h}$ preincubation period with IgE anti-DNP) resulted in a distinct increase in surface C5aR levels but only a weak C3aR upregulation (Fig. 1A). A time course study revealed that stimulation of MC for $1 \mathrm{~h}$ with ionomycin, PMA, or Ag was not sufficient to elevate anaphylatoxin receptor levels whereas $4 \mathrm{~h}$ of incubation resulted in a prominent expression of C5aR (Fig. 1B).

\section{C5a-induced MC functions}

In a next step, we looked for functional consequences of C5aR upregulation. C5a was unable to induce calcium fluxes in resting $\mathrm{MC}$ but, following stimulation with $\mathrm{Ag}$ (after IgE priming) for $4 \mathrm{~h}$ (Fig. 2A) or $24 \mathrm{~h}$ (data not shown), a distinct rise in intracellular calcium was observed. In line with this finding, stimulation with ionomycin (Fig. 2B) or Ag (following IgE priming) (Fig. 2C) augmented $\mathrm{MC}$ chemotaxis toward $\mathrm{C} 5 \mathrm{a}$ in vitro.

Studying MC chemotaxis in an in vivo migration model, the distinction between C5a-induced mobilization of resting and activated MC was even more pronounced. PKH26-labeled MC were recruited into the peritoneal cavity by C5a injections exclusively after stimulation with ionomycin for at least $3 \mathrm{~h}$ (Fig. 3A) or with $\mathrm{Ag}$ (following IgE priming) for not less than $4 \mathrm{~h}$ (Fig. 3B).

Preincubation of activated MC with $\mathrm{C} 5 \mathrm{a}$ abolished the subsequent chemotactic response to $\mathrm{C} 5 \mathrm{a}$ in vivo, most likely as a result of receptor desensitization (Fig. 3C, D). Furthermore, anti-murine C5aR mAb 1240 abrogated in vivo migration of ionomycin-stimuled $\mathrm{MC}$ toward $\mathrm{C} 5 \mathrm{a}$ (Fig. 3E) whereas anti-murine C3aR mAb 1G4 did not. These experiments confirm the receptor-specific nature of C5a-induced MC mobilization in vivo.

In parallel to the rise in C5aR expression on the cell surface (Fig. 1A), PMA-stimulated MC were also mobilized by $\mathrm{C} 5 \mathrm{a}$ in vivo (Fig. 3F).

\section{C3a-induced MC functions}

After establishing the correlation between $\mathrm{MC}$ activation and upregulation of a functional C5aR, C3aR expression and function were also studied. In analogy to C5a, MC activation by $\mathrm{Ag}$ (following IgE priming) or ionomycin increased chemotaxis toward C3a in vitro (Fig. 4A). However, C3a proved to be less efficient (migration optimum at $1000 \mathrm{ng} / \mathrm{ml}$ ) than C5a (optimum at $100 \mathrm{ng} / \mathrm{ml}$ ) and less potent (lower numbers of migrated cells) (Fig. 4B). The specificity of C3a-induced chemotaxis was demonstrated by preincubating MC with C3a which abrogated migration most likely as a consequence of $\mathrm{C} 3 \mathrm{aR}$ desensitization. The low efficiency and potency of $\mathrm{C} 3 \mathrm{a}$ as a $\mathrm{MC}$ chemotaxin was confirmed by our finding that C3a failed to mobilize activated $\mathrm{MC}$ in vivo (Fig. $4 \mathrm{C}$ ) but, on the other hand, recruited human and murine macrophages [[18]; J.Z, personal communication]. Furthermore, C3a wa unable to induce intracellular calcium fluxes in activated MC, in contrast to C5a (Fig. 4D). Proving the functional integrity of the C3a preparation used herein, C3a 

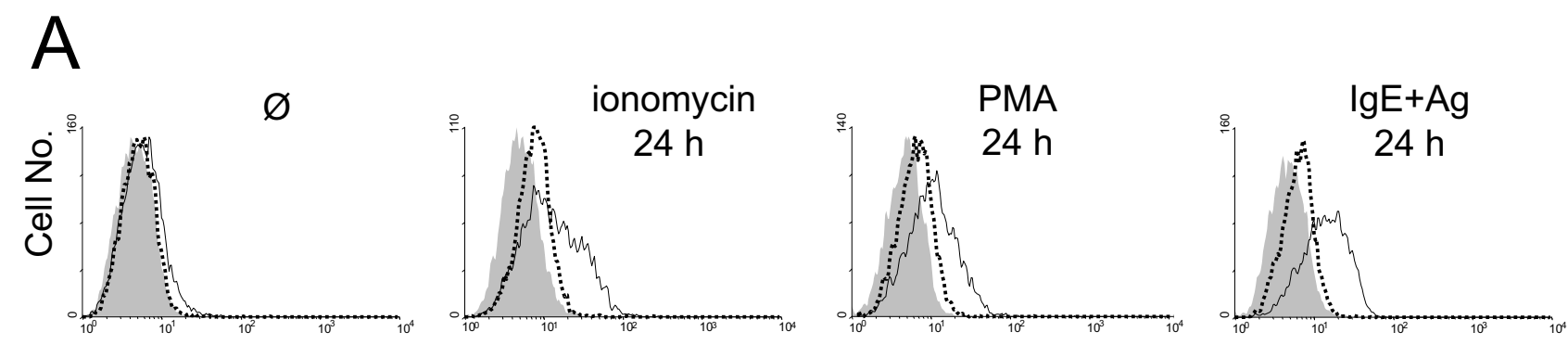

\section{Fluorescence Intensity}
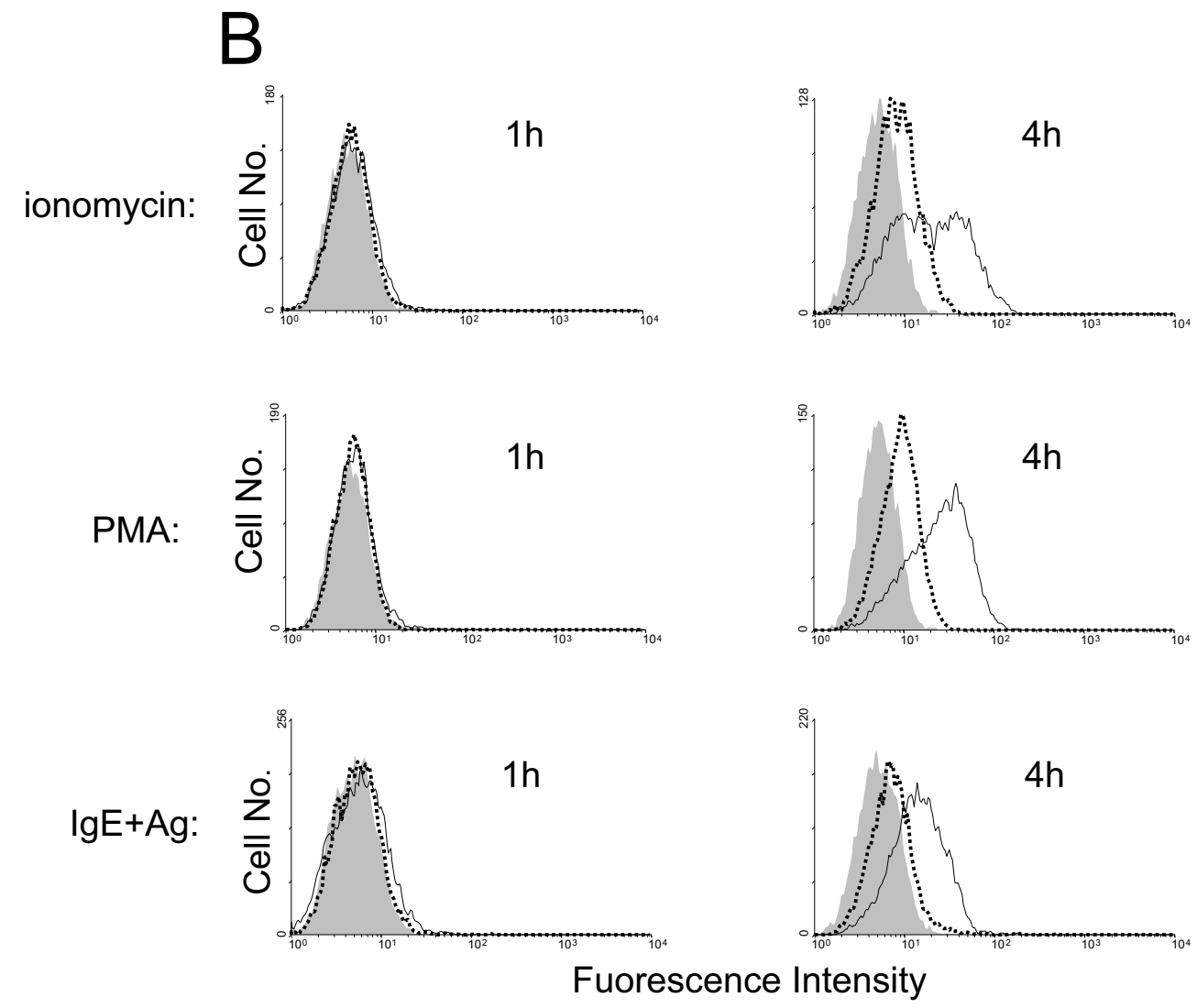

\section{Figure I}

Anaphylatoxin receptors are expressed on activated MC. Precursor cell-derived murine MC cultured with IL-3 and SCF were treated or not $(\varnothing)$ with ionomycin, PMA, or Ag (DNP-albumin, following a $24 \mathrm{~h}$ preincubation period with IgE antiDNP) for $24 \mathrm{~h} \mathrm{(A)}$ or for I $\mathrm{h}$ and $4 \mathrm{~h}$, respectively (B). Subsequently, MC were stained by indirect immunofluorescence and analyzed by FACS. Filled histograms indicate staining with rat IgGI control mAb, open histograms (solid lines) with mAb 1240 against murine $\mathrm{C} 5 \mathrm{aR}$, and open histograms (dotted lines) with mAb IG4 against murine C3aR. One representative experiment each of at least 3 is shown.

was found to be a potent inducer of chemotaxis and calcium release in J774A.1 macrophages (data not shown).

\section{SCF-independent C5aR upregulation}

To exclude an impact of SCF treatment on C5aR expression, we generated $\mathrm{MC}$ in vitro by culturing bone marrowderived precursor cells in the sole presence of IL-3. Fig. 5A demonstrates that MC cultured in the absence of SCF were also subject to upregulation of surface C5aR by stimulation with ionomycin, PMA, or Ag. C5aR on IL-3-treated $\mathrm{MC}$ was functional since they vigorously migrated in vivo in response to $\mathrm{C} 5 \mathrm{a}$ (Fig. 5B). 

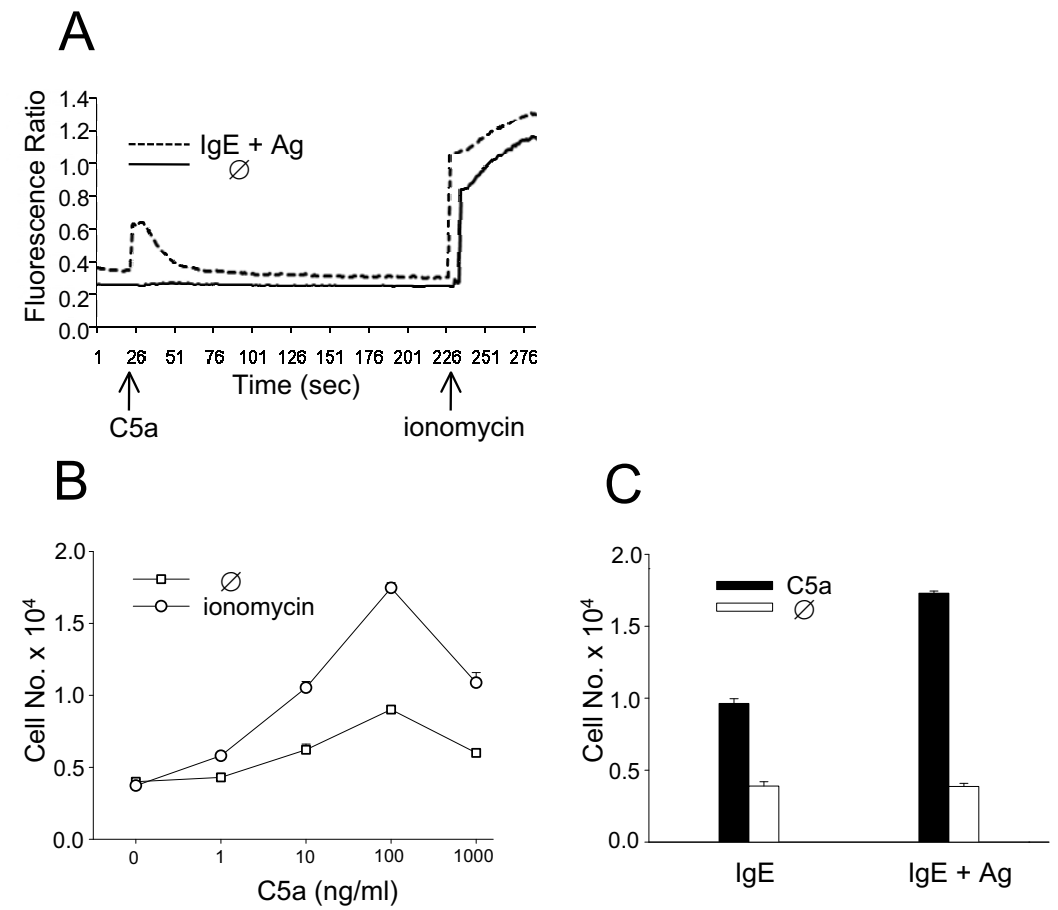

Figure 2

Activated MC respond to $\mathbf{C 5 a}$ in vitro. Precursor cell-derived murine MC cultured with IL-3 and SCF were treated or not (Ø) with $\mathrm{Ag}$ (DNP-albumin, following a $24 \mathrm{~h}$ preincubation period with IgE anti-DNP) for $4 \mathrm{~h}(\mathrm{~A})$ or ionomycin for $24 \mathrm{~h}$ (B). In (C), $M C$ were preincubated with IgE followed or not by $\mathrm{Ag}$ treatment for another $24 \mathrm{~h}$. Subsequently, calcium fluxes in response to $\mathrm{C} 5 \mathrm{a}(\mathrm{I} \mu \mathrm{g} / \mathrm{ml})$ and ionomycin $(750 \mathrm{ng} / \mathrm{ml})(\mathrm{A})$ or in vitro chemotaxis towards $\mathrm{C} 5 \mathrm{a}$ (different concentrations in $\mathrm{B}$; $100 \mathrm{ng} / \mathrm{ml}$ in $C$ ) was measured. One representative experiment of 3 is shown in (A), mean values ( \pm SEM) of 3 independent experiments each in $(B, C)$.

\section{Anaphylatoxin receptors on peritoneal MC}

After establishing the correlation between C5aR expression and cellular activation in precursor cell-derived $\mathrm{MC}$, we also investigated primary $\mathrm{MC}$ obtained from the peritoneal cavity. Similar to in vitro generated $\mathrm{MC}$, activation of peritoneal MC for $1 \mathrm{~h}$ with ionomycin (Fig. 6A) or Ag (following IgE priming) (Fig. 6B) failed to induce C5aR surface expression. After 4 or 24 h of stimulation, however, C5aR expression was extensive whereas C3aR remained undetectable (Fig. 6A, B). C5aR and C3aR were also found to be prominently expressed on resting peritoneal macrophages (Fig. 6C) whereas no other cell type constitutively present in the peritoneal cavity expressed detectable amounts of anaphylatoxin receptors (data not shown).

\section{Discussion}

MC development is a complex process resulting in phenotypically distinct populations at different anatomical sites. In rodents, two MC subsets are discriminated on the basis of different staining characteristics called connective tissue-type MC (CTMC) which are present in the skin and peritoneal cavity, and mucosal MC found in the intestinal or airway mucosa $[19,20]$. In humans, two potentially analogous $\mathrm{MC}$ populations have been defined on the basis of the protease content of their granules with $\mathrm{MC}_{\mathrm{T}}$ containing tryptase and $\mathrm{MC}_{\mathrm{TC}}$ tryptase plus chymase [21].

Murine CTMC from the skin appear to constitutively express $\mathrm{C} 5 \mathrm{aR}$ as they were found to degranulate in response to C5a [15]. Likewise, expression of a functional $\mathrm{C} 5 \mathrm{aR}$ has been detected on human skin-derived $\mathrm{MC}_{\mathrm{TC}}$ as opposed to $\mathrm{MC}_{\mathrm{T}}$ from lung, kidney and intestine [9$12,22,23]$. C5aR was also observed to distinguish the $\mathrm{MC}_{\mathrm{TC}}$ from the $\mathrm{MC}_{\mathrm{T}}$ type of human lung $\mathrm{MC}$ [24]. These findings suggest that $\mathrm{C} 5 \mathrm{aR}$ is constitutively expressed in murine CTMC as well as in human $\mathrm{MC}_{\mathrm{TC}}$. However, $\mathrm{MC}$ phenotypes are also subject to change in the context of inflammation and infection [25]. For example, synovial $\mathrm{MC}_{\mathrm{TC}}$ expressed C5aR exclusively in inflamed tissues of rheumatoid arthritis patients $[13,14]$ raising the possibility that C5aR expression could also depend on variations in the local microenvironment. 

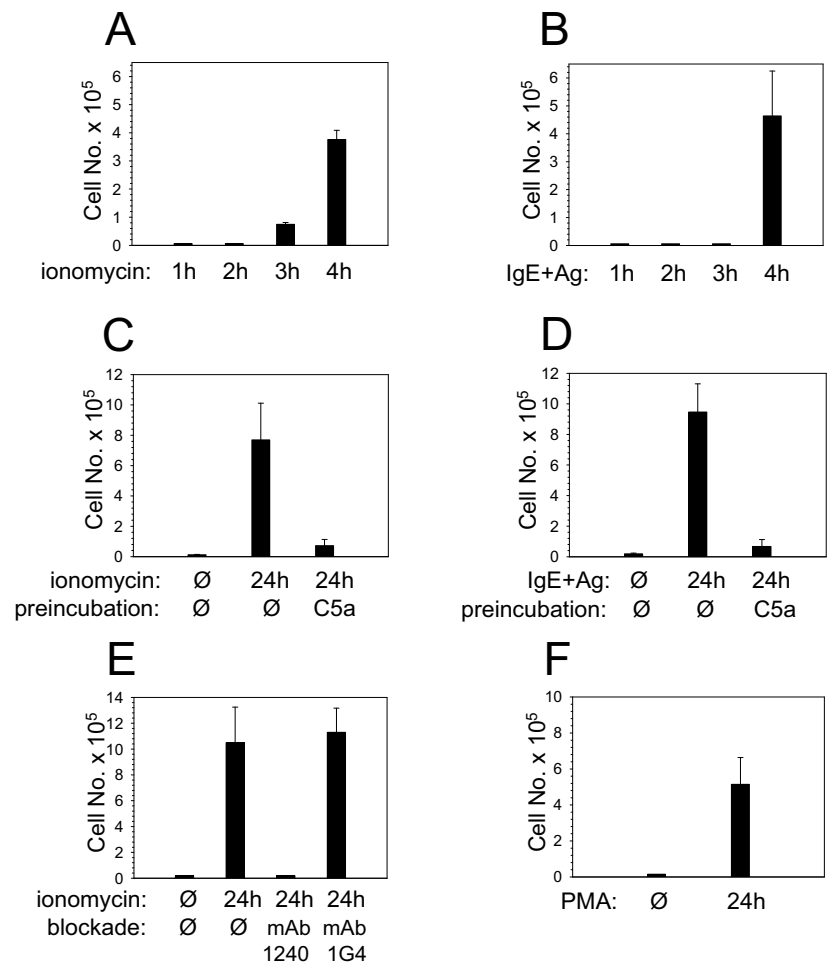

\section{Figure 3}

Activated $\mathrm{MC}$ respond to $\mathbf{C 5 a}$ in vivo. Precursor cellderived murine MC cultured with IL-3 and SCF were treated or not $(\varnothing)$ with ionomycin, PMA or Ag (DNP-albumin, following a $24 \mathrm{~h}$ preincubation period with IgE anti-DNP) for different periods as indicated. Subsequently, $M C$ were labeled with $\mathrm{PKH} 26$. In (C, D), labeled MC were additionally preincubated at $37^{\circ} \mathrm{C}$ without $(\varnothing)$ or with $\mathrm{C} 5 \mathrm{a}(2 \mu \mathrm{g})$ to induce receptor desensitization. In $(E)$, labeled $M C$ were preincubated on ice without $(\varnothing)$ or with $\mathrm{mAb} I 240(20 \mu \mathrm{g}$, rat IgGI) to block C5aR, or with mAb IG4 (20 $\mu$ g, rat IgGI), as a control. Thereafter, labeled $M C$ were injected i.v. into syngeneic $B A L B / c$ mice together with $C 5 a(10 \mu g)$ i.p.. After $4 \mathrm{~h}$ $(A, B, E)$ or $24 \mathrm{~h}(C, D, F)$, peritoneal cells were harvested and labeled migratory cells identified by FACS analysis. Mean values $( \pm$ SEM) of $3(A, B, D)$ or $4(C, E, F)$ independent experiments each are shown.

In the present study, precursor cell-derived murine $\mathrm{MC}$ were found to migrate towards C5a in vitro, confirming previous data $[26,27]$. On the other hand, surface C5aR on cultured, resting $\mathrm{MC}$ was below the theshold of flow cytometric detection which may explain why C5a failed to induce intracellular calcium fluxes and migration in vivo. However, activated MC were distinguished by a prominent $\mathrm{C} 5 \mathrm{aR}$ expression and vigorous functional responsiveness to C5a in vitro as well as in vivo which required approximately $4 \mathrm{~h}$ of stimulation by Ag (subsequent to IgE primimg), ionomycin, or PMA. As the signaling cascade downstream of the high affinity receptor for $\mathrm{IgE}$,
FceRI, also results in PKC activation and intracellular calcium fluxes [28], it remains to be shown if other physiologic MC activators may stimulate C5aR upregulation as well.

SCF which leads to the activation of muliple signaling pathways after binding to its receptor induces IL-3dependent $\mathrm{MC}$ to mature and acquire characteristics of CTMC $[29,30]$. Our study demonstrates, however, that the capacity of precursor cell-derived MC to upregulate a functional C5aR was independent of SCF-induced MC differentiation. This finding could indicate that the activationinduced neoexpression of surface C5aR on MC may not be restricted to CTMC. Further detailed studies are needed to resolve this issue.

Having established the correlation between $\mathrm{MC}$ activation and $\mathrm{C} 5 \mathrm{aR}$ expression in precursor cell-derived $\mathrm{MC}$, we also studied primary murine $\mathrm{MC}$ obtained from the peritoneal cavity which have characteristics of CTMC. Originally, peritoneal $\mathrm{MC}$ were described to be unresponsive to C5a [15]. Recently, however, a study utilizing genetically deficient mice suggested $\mathrm{C} 5 \mathrm{aR}$ on peritoneal MC to be instrumental in a model of zymosan-induced peritonitis [16]. The evidence presented herein clearly indicates that resting peritoneal $\mathrm{MC}$ lack surface $\mathrm{C} 5 \mathrm{aR}$ which is in accordance with the original finding of Lim et al. (1991). However, following stimulation with Ag (subsequent to IgE priming) or ionomycin, we found peritoneal $\mathrm{MC}$ to acquire an inflammatory phenotype distinguished by a prominent $\mathrm{C} 5 \mathrm{aR}$ expression. Thus, one may hypothesize that peritoneal $\mathrm{MC}$ gain responsiveness to $\mathrm{C} 5 \mathrm{a}$ by $\mathrm{C} 5 \mathrm{aR}$ upregulation as a consequence of zymosan-induced inflammation which is additionally characterized by the accumulation of $\mathrm{C} 5 \mathrm{a}$ due to the vigorous activation of the complement cascade.

C3a was found to be a potent chemotaxin for HMC-1 mast cells $[11,12]$. However, this tumor cell line may not be fully representative for primary human $\mathrm{MC}$ since tumor transformation may substantially alter normal cell functions. Investigating skin-derived human MC, Hartmann et al. [12] found that C3a chemoattracted only one out of two MC preparations whereas C5a was effective in both. Likewise, El-Lati et al. [8] reported C3a to be a weak inducer of histamin release as compared to C5a. Notably, rat peritoneal $\mathrm{MC}$ responded to $\mathrm{C} 3 \mathrm{a}$ in a receptor-independent manner [17]. In agreement with these observations, we found murine peritoneal $\mathrm{MC}$ to lack surface $\mathrm{C} 3 \mathrm{aR}$, the expression of which, in contrast to $\mathrm{C} 5 \mathrm{aR}$, was not inducible by MC activation. Furthermore, the activation-induced upregulation of $\mathrm{C} 3 \mathrm{aR}$ in precursor cellderived MC was low as compared to C5aR and C3a, in contrast to $\mathrm{C} 5 \mathrm{a}$, was unable to stimulate calcium fluxes in activated $\mathrm{MC}$ or mobilize these cells in vivo. 

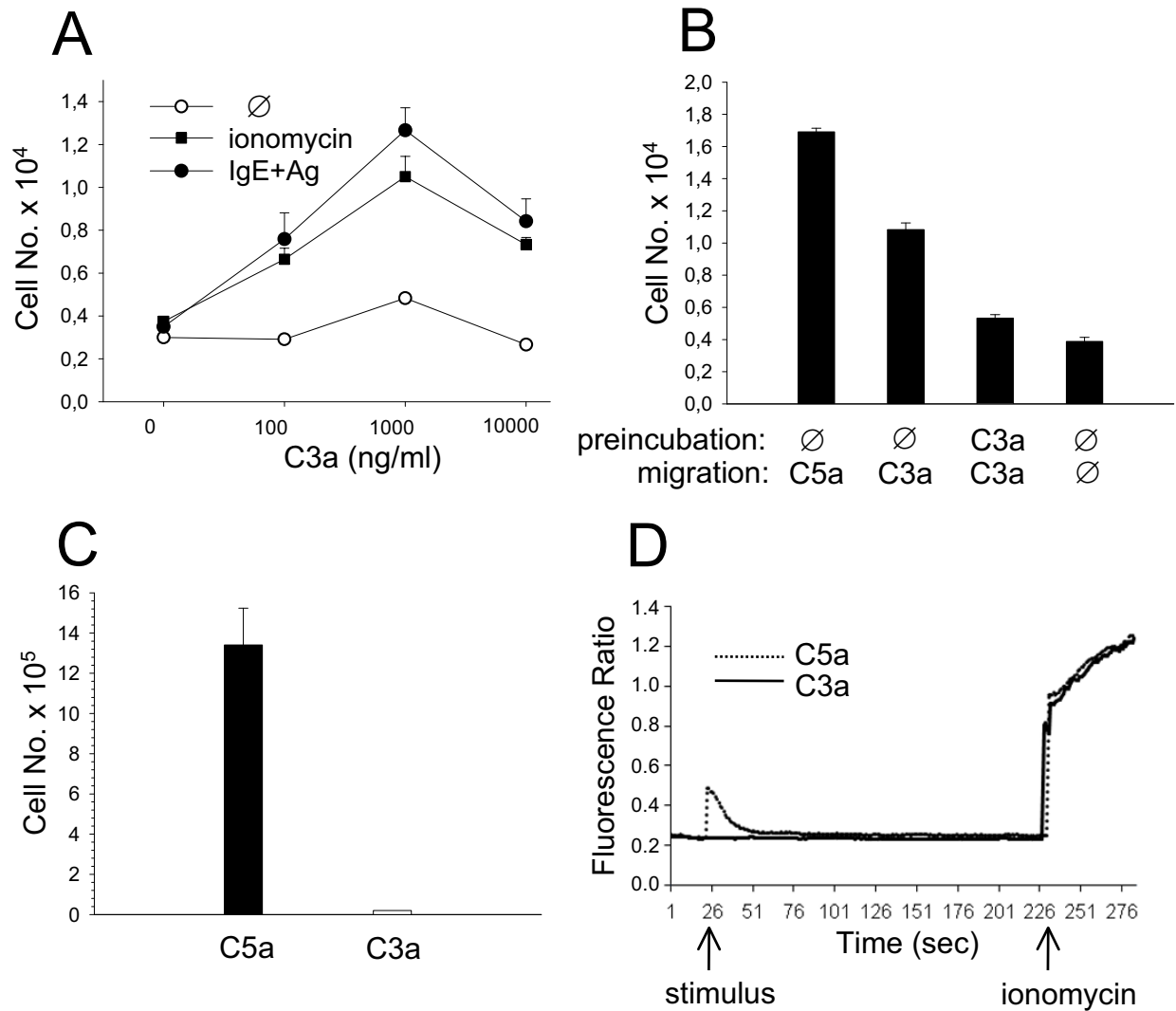

\section{Figure 4}

C3a is a weak MC chemotaxin. Precursor cell-derived murine MC cultured with IL-3 and SCF were treated or not ( $\varnothing$ ) with ionomycin (A-C) or Ag (DNP-albumin, following a $24 \mathrm{~h}$ preincubation period with IgE anti-DNP) (A, D) for 24 h. Subsequently, in vitro chemotaxis towards different concentrations of $\mathrm{C} 3 \mathrm{a}(\mathrm{A})$ or optimal concentrations of $\mathrm{C} 5 \mathrm{a}(\mathrm{I} 00 \mathrm{ng} / \mathrm{ml}) \mathrm{and}$ $\mathrm{C} 3 \mathrm{a}(1000 \mathrm{ng} / \mathrm{ml})(\mathrm{B})$ was measured. In (B), MC were additionally preincubated at $37^{\circ} \mathrm{C}$ without $(\varnothing)$ or with $\mathrm{C} 3 \mathrm{a}$ to induce receptor desensitization. In (C), $\mathrm{MC}$ were labeled with $\mathrm{PKH} 26$ and injected i.v. into syngeneic BALB/c mice together with $\mathrm{C} 5 \mathrm{a}$ $(10 \mu \mathrm{g})$ or $\mathrm{C} 3 \mathrm{a}(50 \mu \mathrm{g})$ i.p.. $24 \mathrm{~h}$ later, peritoneal cells were harvested and labeled migratory cells identified by FACS analysis. In (D), calcium fluxes in response to $\mathrm{C} 3 \mathrm{a}(10 \mu \mathrm{g} / \mathrm{ml})$ or $\mathrm{C} 5 \mathrm{a}(\mathrm{I} \mu \mathrm{g} / \mathrm{ml})$ and ionomycin $(750 \mathrm{ng} / \mathrm{ml})$ were measured. Mean values $( \pm$ SEM) of 3 independent experiments each (A-C) and I representative experiment of 3 (D) are shown.

Thus, our findings argue against a significant role for $\mathrm{C} 3 \mathrm{aR}$ in MC-mediated pathogenesis. In accordance with this hypothesis, immune complex-induced skin injury and peritonitis were found to be dependent on $\mathrm{MC}$ and $\mathrm{C} 5 \mathrm{aR}$, but not C3aR or C3 [31,32]. It is important to note, however, that the results and conclusions of the present study exclusively refer to the mouse.

\section{Conclusion}

Our study demonstrates for the first time that Ag-dependent as well as -independent activation induces an inflammatory $\mathrm{MC}$ phenotype which is distinguished by neoexpression of a functional $\mathrm{C} 5 \mathrm{aR}$ as a novel effector mechanism in MC-mediated pathogenesis.

\section{Methods}

Reagents

Recombinant murine IL-3 and SCF were obtained from PeproTech (Cell Concepts, Umkirch, Germany). Recombinant human C5a was described elsewhere [18]. Recombinant human C3a and PMA were from Calbiochem (Merck Biosciences, Darmstadt, Germany). Ionomycin, monoclonal murine IgE anti-DNP, and DNP-albumin were from Sigma-Aldrich (Deisenhofen, Germany).

\section{Monoclonal Ab against murine C5aR and C3aR}

Anti-murine C3aR mAb 1G4 (rat IgG1) has been described by us [33]. Our laboratory has also reported generation of several mAbs against murine C5aR [34]. From that fusion, mAb 1240 was now selected for use in 

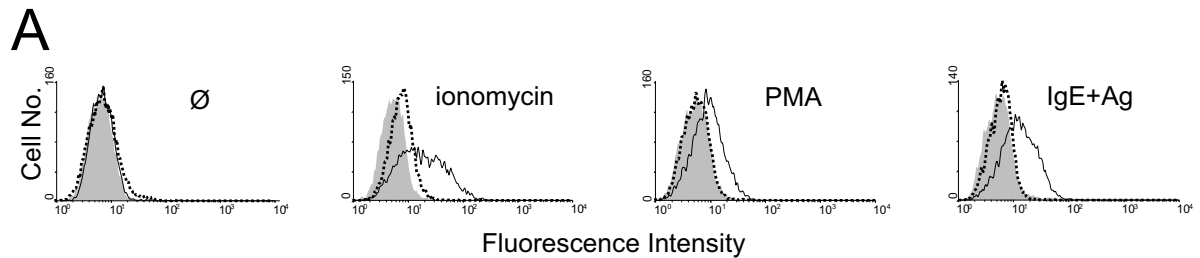

Fluorescence Intensity
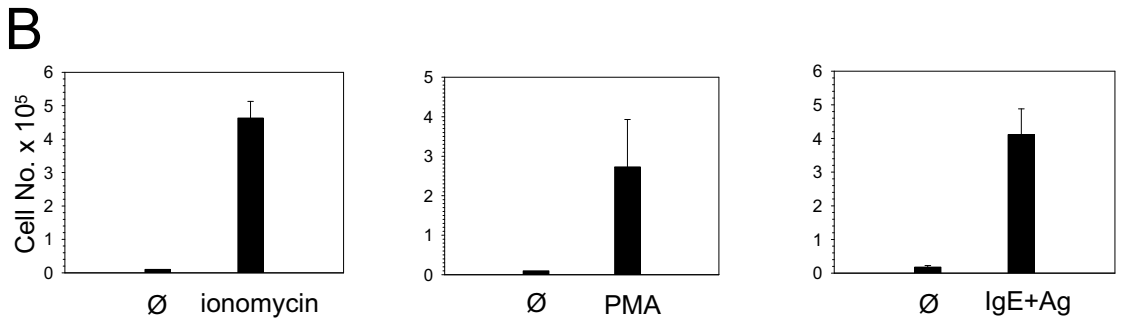

\section{Figure 5}

C5aR upregulation is independent of SCF treatment. Precursor cell-derived murine MC cultured with IL-3 were treated or not $(\varnothing)$ with ionomycin, PMA, or Ag (DNP-albumin, following a $24 \mathrm{~h}$ preincubation period with IgE anti-DNP) for 24 $h(A)$ or $4 \mathrm{~h}(B)$. In (A), MC were stained by indirect immunofluorescence and analyzed by FACS. Filled histograms indicate staining with rat IgGI control mAb, open histograms (solid lines) with mAb 1240 against murine C5aR, and open histograms (dotted lines) with mAb IG4 against murine C3aR. In (B), MC were labeled with PKH26 and injected i.v. into syngeneic BALB/ c mice together with $\mathrm{C} 5 \mathrm{a}(10 \mu \mathrm{g})$ i.p.. $24 \mathrm{~h}$ later, peritoneal cells were harvested and labeled migratory cells identified by FACS analysis. One representative experiment of $3(A)$ and mean values $( \pm$ SEM) of 4 independent experiments each (B) are shown.

A
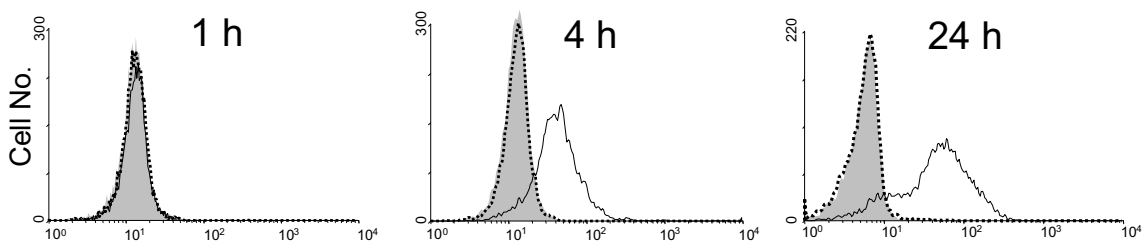

Fluorescence Intensity
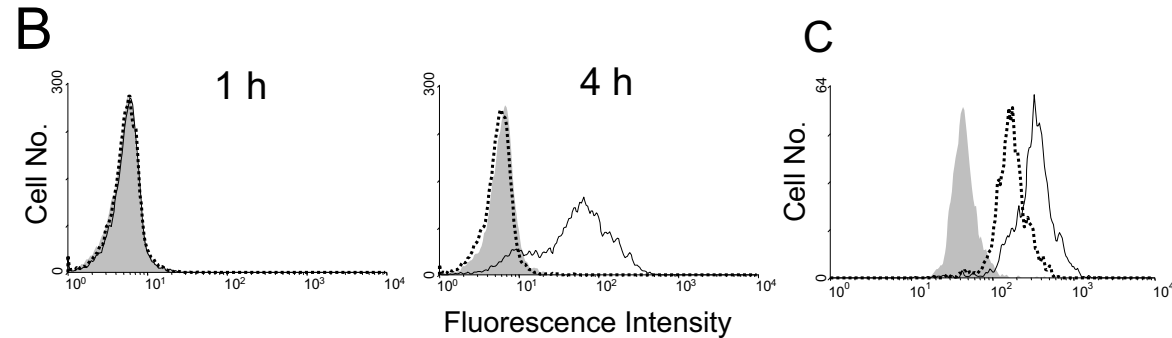

\section{Figure 6}

Activation of peritoneal MC induces C5aR upregulation. Peritoneal MC from BALB/c mice were purified by a negative selection technique and cultured with ionomycin (A) or Ag (DNP-albumin, following a $24 \mathrm{~h}$ preincubation period with IgE antiDNP) (B) for different periods as indicated. Subsequently, MC were stained by indirect immunofluorescence and analyzed by

FACS. Gates were set on $C D I I 7^{+} M C(A, B)$. In (C), untreated peritoneal lavage cells were stained by indirect immunofluorescence and gates set on $\mathrm{F} 4 / 80^{+}$macrophages. Filled histograms indicate staining with rat lgGI control mAb, open histograms (solid lines) with mAb 1240 against murine C5aR, and open histograms (dotted lines) with mAb IG4 against murine C3aR. One representative experiment each of 3 is shown. 
the present study as its isotype (rat IgG1) was identical to mAb 1G4.

\section{Murine MC preparations}

Murine precursor cell-derived MC were generated as described [35,36], with minor modifications. In brief, bone marrow was collected from tibias and femurs of female $\mathrm{BALB} / \mathrm{C}$ mice, passed through a nylon mesh to remove small pieces of bone and debris, resuspended in complete medium (RPMI 1640 containing 10\% FCS, 0.1 $\mathrm{mM}$ nonessential aa, $2 \mathrm{mM}$ L-glutamine, $100 \mathrm{U} / \mathrm{ml}$ penicillin, $100 \mu \mathrm{g} / \mathrm{ml}$ streptomycin, $1 \mathrm{mM}$ sodium pyruvate, $50 \mu \mathrm{M} 2-\mathrm{ME}$ ), and cultured for $2 \mathrm{~h}$. Nonadherent cells were collected, and aliquots of $5 \times 10^{5}$ cells placed in 24 well plates containing $1 \mathrm{ml}$ of complete medium together with murine IL-3 in the presence or absence of murine SCF $(10 \mathrm{ng} / \mathrm{ml}$ each). Two-thirds of the medium was replaced every 3-4 days. After 5-10 weeks, more than $95 \%$ of nonadherent cells were MC, as judged by morphology, surface expression of CD117 and IgE binding. MC were activated either with ionomycin $(750 \mathrm{ng} / \mathrm{ml})$ or PMA $(50 \mathrm{ng} / \mathrm{ml})$ for different periods as indicated or, in an Ag-specific manner, by preincubation with monoclonal murine IgE anti-DNP $(2 \mu \mathrm{g} / \mathrm{ml})$ for $24 \mathrm{~h}$ followed by the Ag DNP-albumin $(50 \mu \mathrm{g} / \mathrm{ml})$ for different periods as indicated.

Peritoneal MC were purified from lavage cells of BALB/C mice by magnetic cell sorting using a negative selection technique to avoid MC activation. For this purpose, approximately $1 \times 10^{8}$ peritoneal cells were incubated with FITC-anti-CD90 (clone 30H12) and FITC-anti-CD19 (clone 6D5) and T- and B-cells deleted by incubation with anti-FITC immunomagnetic microbeads and high-gradient LS separation columns. In a second step, remaining cells were incubated with FITC-anti-CD11b (clone M1/ 70), FITC-anti-CD11c (clone N418), FITC-anti-Gr1 (clone RB6-8C5), and FITC-anti-CD49b (clone DX5). Subsequently, monocytes, DC, granulocytes, and NK cells, respectively, were deleted using anti-FITC immunomagnetic microbeads and high-gradient LS separation columns. All $\mathrm{mAb}$ and reagents were obtained from Miltenyi Biotec (Bergisch-Gladbach, Germany). Following this procedure, $5 \times 10^{5}$ to $8 \times 10^{5}$ cells were recovered which were $>80 \% \mathrm{MC}$ as judged by CD117 surface expression. Purified peritoneal MC were either immediately used for staining and FACS analysis or cultured in complete medium as indicated.

\section{In vitro chemotaxis}

In vitro chemotaxis was assayed using the HTS Transwell24 system from Corning (Beyer Lab., Düsseldorf, Germany). Cells diluted at $1 \times 10^{6} / \mathrm{ml}$ in migration buffer (RPMI 1640 with 1\% BSA) were placed in the upper wells whereas anaphylatoxins diluted in migration buffer as indicated were added to the lower wells. Polycarbonate membranes with a pore size of $5 \mu \mathrm{m}$ were used and incubation was performed at $37^{\circ} \mathrm{C}$ in a $5 \% \mathrm{CO}_{2}$ atmosphere for $3 \mathrm{~h}$. Migration was stopped and migrated cells detached by placing Transwell chambers for $15 \mathrm{~min}$ on ice. Subsequently, migrated cells in the lower chambers were counted using a hemocytometer. All determinations were performed in duplicate.

For desensitization studies, cells $\left(1 \times 10^{6}\right.$ in $1 \mathrm{ml}$ medium $)$ were preincubated at $37^{\circ} \mathrm{C}$ for $30 \mathrm{~min}$ with the indicated anaphylatoxin $(200 \mathrm{ng} / \mathrm{ml})$ and centrifuged.

\section{In vivo migration model}

All animal work was conducted in accordance with guidelines for animal welfare and was approved by the government of Lower Saxony, Germany. In vivo migration was studied as described elsewhere [18]. Murine bone marrow-derived MC were labeled with the red fluorescent dye PKH-26 (Sigma-Aldrich) according to the manufacturer's instructions. Cells $\left(1 \times 10^{7}\right.$ in $200 \mu \mathrm{l}$ PBS $)$ were then injected into the tail vein of BALB/c mice (weight 20-24 g; age 8-20 wk) together with a chemotaxin (10 $\mu$ g C5a or $50 \mu \mathrm{g} \mathrm{C} 3 \mathrm{a}$; in $200 \mu \mathrm{l} \mathrm{PBS}$ ) which was injected into the peritoneal cavity. Approximately $24 \mathrm{~h}$ later, mice were sacrificed and peritoneal lavage performed. Subsequently, peritoneal cells were counted and analyzed by FACS. Absolute numbers of migrated labeled cells were calculated from the percentage of red fluorescent cells as determined by FACS analysis and the total peritoneal cell count.

For C5aR blockade, labeled MC $\left(1 \times 10^{7}\right.$ in $1 \mathrm{ml}$ PBS $)$ were preincubated on ice for $45 \mathrm{~min}$ with $20 \mu \mathrm{g}$ of mAb 1240 (or, as a control, mAb 1G4; both are rat IgG1), washed twice with PBS and resuspended in $200 \mu \mathrm{l}$ PBS for injection.

For desensitization studies, labeled MC $\left(1 \times 10^{7}\right.$ in $1 \mathrm{ml}$ PBS) were preincubated at $37^{\circ} \mathrm{C}$ for $1 \mathrm{~h}$ with $2 \mu \mathrm{g}$ of anaphylatoxin as indicated, washed twice in PBS and resuspended in $200 \mu \mathrm{l}$ PBS for injection.

\section{Calcium measurements}

A total of $10^{6}$ cells were loaded in $700 \mu$ RPMI containing 5\% FCS, $1 \mu \mathrm{M}$ Fluo3-AM and 0.02\% Pluronic F127 (both from Molecular Probes, Invitrogen, Karlsruhe, Germany). Subsequently, the cell suspension was diluted 2-fold with RPMI $10 \%$ FCS and was incubated for $10 \mathrm{~min}$ at $37^{\circ} \mathrm{C}$. Cells were washed twice with Krebs Ringer solution composed of $10 \mathrm{mM}$ HEPES (pH 7.0), $140 \mathrm{mM} \mathrm{NaCl}, 4 \mathrm{mM}$ $\mathrm{KCl}, 1 \mathrm{mM} \mathrm{MgCl}_{2}, 1 \mathrm{mM} \mathrm{CaCl}_{2}$, and $10 \mathrm{mM}$ glucose. The changes in fluorescence intensity of Fluo3 were monitored on a LSRII cytometer (BD Biosciences, Heidelberg, 
Germany). Loading of the samples was controlled by treatment with $750 \mathrm{ng} / \mathrm{ml}$ ionomycin.

\section{FACS analysis}

For indirect immunofluorescence analysis, $\mathrm{MC}\left(2 \times 10^{5}\right.$ in $100 \mu \mathrm{l}$ ) were washed with PBS containing $1.5 \%$ FCS and $0.1 \% \mathrm{NaN}_{3}$ and blocked with heat aggregated human IgG $(20 \mu \mathrm{g})$ for $20 \mathrm{~min}$ on ice. After a washing step, primary $\mathrm{mAb}$ in PBS containing 1.5\% FCS, heat aggregated human IgG $(10 \mu \mathrm{g}$ in $100 \mu \mathrm{l})$ and $0.1 \% \mathrm{NaN}_{3}$ were added and incubated for $45 \mathrm{~min}$ on ice. After washing cells three times in PBS $/ 1.5 \%$ FCS $/ 0.1 \% \mathrm{NaN}_{3}$, biotin-conjugated mouse anti-rat IgG1 (BD Biosciences) was added for another $45 \mathrm{~min}$. After washing cells three times in PBS/ $1.5 \% \mathrm{FCS} / 0.1 \% \mathrm{NaN}_{3}$, streptavidin-FITC (Dako, Hamburg, Germany) was added for another $45 \mathrm{~min}$. If peritoneal cells were studied, PE-anti-murine CD117 (rat IgG2b; Miltenyi Biotec) or PE-anti-F4/80 (Caltag Lab., Hamburg, Germany) were included in this step to identify $\mathrm{MC}$ or macrophages. Finally, cells were washed three times in PBS $/ 1.5 \%$ FCS $/ 0.1 \% \mathrm{NaN}_{3}$, resuspended in PBS containing $1 \%$ formaldehyde and analyzed by flow cytometry (FACSCalibur; BD Biosciences). If peritoneal cells were studied, gates were set on CD117+ MC or F4/ $80+$ macrophages.

The following primary $\mathrm{mAb}$ were used at a concentration of $5 \mu \mathrm{g} / \mathrm{ml}$ : anti-murine C5aR mAb 1240 (rat IgG1), antimurine C3aR mAb 1G4 (rat IgG1), isotype control mAb rat IgG1 (BD Biosciences).

\section{Abbreviations}

MC: mast cell; CTMC: connective tissue-type MC; C5aR: C5a receptor; C3aR: C3a receptor.

\section{Authors' contributions}

AS, JG, ZK and JZ were all involved in the study design, data acquisition, analysis and interpretation. JZ drafted the manuscript. All authors read and approved the final manuscript.

\section{Acknowledgements}

This work was supported by a grant from the Deutsche Forschungsgemeinschaft to J.Z. (ZW 38/3). The authors would like to thank Olga Walter for excellent technical assistance.

\section{References}

I. Walport MJ: Advances in immunology: complement. N Engl J Med 200I, 344:1058-1066.

2. Guo RF, Ward PA: Role of C5a in inflammatory responses. Annu Rev Immunol 2005, 23:82 I-852.

3. Haas PJ, van Strijp J: Anaphylatoxins: their role in bacterial infection and inflammation. Immunol Res 2007, 37:161-175.

4. Köhl J, Wills-Karp M: A dual role for complement in allergic asthma. Curr Opin Pharmacol 2007, 7:283-289.

5. Benoist C, Mathis D: Mast cells in autoimmune disease. Nature 2002, 420:875-880

6. Boyce JA: Mast cells: beyond IgE. J Allergy Clin Immunol 2003, I I I:24-32.
7. Schulman ES, Post TJ, Henson PM, Giclas PC: Differential effects of the complement peptides, C5a and C5a(desArg), on human basophils and lung mast cell histamine release. J Clin Invest 1988, 81:918-923.

8. El-Lati SG, Dahinden CA, Church MK: Complement peptides C3a- and C5a-induced mediator release from dissociated human skin mast cells. J Invest Dermatol 1994, 102:803-806.

9. Füreder W, Agis H, Willheim M, Bankl HC, Maier U, Kishi K, Müller MR, Czerwenka K, Radaskiewicz T, Butterfield JH, Klappacher GW, Sperr WR, Oppermann M, Lechner K, Valent P: Differential expression of complement receptors on human basophils and mast cells: evidence for mast cell heterogeneity and CD88/C5aR expression on skin mast cell. J Immunol 1995, I55:3152-3160.

10. Werfel T, Zwirner J, Oppermann M, Sieber A, Begemann G, Drommer W, Kapp A, Götze O: CD88 antibodies specifically bind to C5aR on dermal CDII 7+ and CDI4+ cells and react with a desmosomal antigen in human skin. J Immunol 1996, 157:1729-1735

II. Nilsson G, Johnell M, Hammer CH, Tiffany HL, Nilsson K, Metcalfe DD, Siegbahn A, Murphy PM: C3a and C5a are chemotaxins for human mast cells and act through distinct receptors via a pertussis toxin-sensitive signal transduction pathway. J Immunol 1996, 157:1693-1698.

12. Hartmann K, Henz BM, Krüger-Krasagakes S, Köhl J, Burger R, Guhl $\mathrm{S}$, Haase I, Lippert U, Zuberbier T: C3a and C5a stimulate chemotaxis of human mast cells. Blood 1997, 89:2863-2870.

13. De Paulis A, Marino I, Cicarelli A, de Crescenzo G, Concardi M, Verga L, Marone G: Human synovial mast cells. I. Ultrastructural in situ and in vitro immunologic characterization. Arthritis Rheum 1996, 39:1222-1233.

14. Kiener HP, Baghestanian M, Dominkus M, Walchshofer S, Ghannadan M, Sillaber C, Graninger WB, Smolen JS, Valent P: Expression of the C5a receptor (CD88) on synovial mast cells in patients with rheumatoid arthritis. Arthritis Rheum 1998, 41:233-245.

15. Lim HW, He D, Esquenazi-Behar S, Yancey KB, Soter NA: C5a, cutaneous mast cells, and inflammation: in vitro and in vivo studies in a murine model. J Invest Dermatol 199I, 97:305-3I I.

16. Mullaly SC, Kubes P: Mast cell-expressed complement receptor, not TLR2, is the main detector of zymosan in peritonitis. Eur J Immunol 2007, 37:224-234.

17. Mousli M, Hugli TE, Landry Y, Bronner C: A mechanism of action for anaphylatoxin C3a stimulation of mast cells. J Immunol 1992, 148:2456-2461.

18. Soruri A, Kiafard Z, Dettmer C, Riggert J, Kohl J, Zwirner J: IL-4 down-regulates anaphylatoxin receptors in monocytes and dendritic cells and impairs anaphylatoxin-induced migration in vivo. J Immunol 2003, 170:3306-33।4.

19. Galli SJ: New insights into "the riddle of the mast cells": microenvironmental regulation of mast cell development and phenotypic heterogeneity. Lab lnvest 1990, 62:5-33.

20. Marshall JS: Mast-cell responses to pathogens. Nat Rev Immunol 2004, 4:787-799.

21. Irani AA, Schechter NM, Craig SS, De Blois G, Schwartz LB: Two types of human mast cells that have distinct neutral protease compositions. Proc Natl Acad Sci USA 1986, 83:4464-4468.

22. Beil WJ, Füreder W, Wiener H, Grossschmidt K, Maier U, Schedle A, Bankl HC, Lechner K, Valent P: Phenotypic and functional characterization of mast cells derived from renal tumor tissues. Exp Hematol 1998, 26:158-169.

23. Bischoff SC, Schwengberg S, Wordelmann K, Weimann A, Raab R, Manns MP: Effect of c-kit ligand, stem cell factor, on mediator release by human intestinalmast cells isolated from patients with inflammatory bowel disease and controls. Gut 1996, 38:104-II4.

24. Oskeritzian CA, Zhao W, Min H-K, Xia H-Z, Pozez A, Kiev J, Schwartz LB: Surface CD88 functionally distinguishes the $M C_{T C}$ from the $M_{C_{T}}$ type of human lung mast cells. J Allergy Clin Immunol 2006, I I 5: I I62-1 I 68.

25. Metz M, Maurer M: Mast cells-key effector cells in immune responses. Trends Immunol 2007, 28:234-24I.

26. Nilsson G, Metcalfe DD, Taub DD: Demonstration that plateletactivating factor is capable of activating mast cells and inducing a chemotactic response. Immunology 2000, 99:314-319.

27. Jackson NE, Wang H-W, Tedla N, McNeil HP, Geczy CL, Collins A, Grimm MC, Hampartzoumian T, Hunt JE: IL-I 5 induces mast cell 
migration via a pertussis toxin-sensitive receptor. Eur J Immunol 2005, 35:2376-2385.

28. Gilfillan AM, Tkaczyk C: Integrated signalling pathways for mast-cell activation. Nat Rev Immunol 2006, 6:2 I 8-230.

29. Tsai M, Takeishi T, Thompson H, Langley K, Zsebo KM, Metcalfe DD, Geissler EN, Galli SJ: Induction of mast cell proliferation, maturation, and heparin synthesis by the rat c-kit ligand, stem cell factor. Proc Natl Acad Sci USA 1991, 88:6282-6286.

30. Reber L, Da Silva CA, Frossard N: Stem cell factor and its receptor c-Kit as targets for inflammatory diseases. Eur J Pharmacol 2006, 533:327-340.

31. Baumann U, Chouchakova N, Gewecke B, Köhl J, Carroll MC, Schmidt RE, Gessner JE: Distinct tissue site-specific requirements of mast cells and complement components C3/C5a receptor in IgG immune complex-induced injury of skin and lung. J Immunol 200I, 167:1022-1027.

32. Godau J, Heller T, Hawlisch H, Trappe M, Howells E, Best J, Zwirner J, Verbeek JS, Hogarth PM, Gerard C, van Rooijen N, Klos A, Gessner JE, Köhl J: C5a initiates the inflammatory cascade in immune complex peritonitis. J Immunol 2004, 173:3437-3445.

33. Kiafard Z, Tschernig T, Schweyer S, Bley A, Neumann D, Zwirner J: Use of monoclonal antibodies to assess expression of anaphylatoxin receptors in tubular epithelial cells of human, murine and rat kidneys. Immunobiol 2007, 2 I 2: I29-139.

34. Soruri A, Kim S, Kiafard Z, Zwirner J: Characterization of C5aR expression on murine myeloid and lymphoid cells by the use of a novel monoclonal antibody. Immunol Lett 2003, 88:47-52.

35. Orinska Z, Bulanova E, Budagian V, Metz M, Maurer M, Bulfone-Paus S: TLR3-induced activation of mast cells modulates CD8+ Tcell recruitment. Blood 2005, 106:978-987.

36. Mullaly SC, Kubes $P$ : The role of TLR2 in vivo following challenge with staphylococcus aureus and prototypic ligands. J Immunol 2006, 177:8I54-8I63.

\section{Publish with Bio Med Central and every scientist can read your work free of charge}

"BioMed Central will be the most significant development for disseminating the results of biomedical research in our lifetime. "

Sir Paul Nurse, Cancer Research UK

Your research papers will be:

- available free of charge to the entire biomedical community

- peer reviewed and published immediately upon acceptance

- cited in PubMed and archived on PubMed Central

- yours - you keep the copyright

Submit your manuscript here:

http://www.biomedcentral.com/info/publishing_adv.asp
BiolMedcentral 